\title{
Strategi Pengembangan Usaha Penggemukan Ternak Sapi Potong di Kelompok Tani Nekmese di Desa Usapinonot Kecamatan Insana Barat
}

\section{Frederikus Nofrianto Liu ${ }^{\mathrm{a}}$}

${ }^{a}$ Fakultas Pertanian, Universitas Timor, Kefamenanu, TTU - NTT, Indonesia.

\section{Article Info}

\section{Article history:}

Received 28 Agustus 2018

Received in revised form 21 September 2018 Accepted 5 Oktober 2018

\section{DOI:}

https://doi.org/10.32938/ag.v3i4.326

Strategi Pengembangan

Sapi Potong

Nekmese

\section{Abstrak}

Agar usaha ternak sapi potong yang berkembang dengan baik dan memberikan manfaat bagi para anggota kelompok tani maka perlu ditentukan strategi pengembangan usaha yang tepat. Tujuan dari penelitian ini untuk mengetahui 1) gambaran kelompok tani usaha penggemukan ternak sapi potong; 2) mengetahui strategi pengembangan usaha penggemukan ternak sapi potong di kelompok tani Nekmese, Desa Usapinonot, Kecamatan Insana Barat, Kabupaten TTU. Penelitian ini telah dilaksanakan pada bulan November 2017 sampai April 2018. Untuk mengetahui tujuan pertama digunakan analisis deskriptif. Sedangkan untuk mengetahui strategi yang tepat dalam pengembangan sapi potong digunakan matriks SWOT. Berdasarkan hasil penelitian, alternatif strategi S-O yang dirumuskan yaitu i) meningkatkan jumlah ternak sapi potong untuk memenuhi kebutuhan pasar; ii) mengoptimalkan kemampuan peternak dalam mengembangkan usaha penggemukan ternak sapi potong; dan iii) ciptakan suatu wadah yang dapat menampung dan mengelola sendiri modal usaha kelompok. Alternatif strategi W-O yang dirumuskan yaitu i) mengembangkan dan meningkatkan kemampuan SDM peternak dalam berusaha ternak sapi potong; dan ii) membuka peluang jaringan kerjasama dengan berbagai pihak baik dalam hal pengembangan usaha maupun pemasaran ternak. Alternatif strategi S-T yang dirumuskan yaitu i) mengadakan pelatihan pengenalan pakan dan waktu pengambilan pakan serta pemberian pakan; dan ii) pengadaan pelatihan mengenai penggunaan obat-obatan dan pemberian kekebalan tubuh serta sanitasi yang aman bagi ternak sapi potong. Alternatif strategi W-T yang dirumuskan yaitu i) mengadakan pelatihan dan pemberdayaan kepada peternak dan SDM petugas teknis peternakan di desa; dan ii) melakukan pembinaan atau pelatihan-pelatihan kepada peternak untuk meningkatkan dan mempertahankan bobot badan maupun kualitas ternak sapi potong.

\section{Pendahuluan}

Sapi merupakan salah satu jenis ternak yang digemari dan banyak diusahakan oleh peternak di Indonesia, khususnya sapi potong yang merupakan ternak penghasil daging yang memiliki kandungan protein serta nilai ekonomis tinggi. Usaha peternakan sapi potong di Indonesia umumnya masih bersifat tradisional (Kurniawan, 2012), walaupun ada beberapa daerah di Pulau Jawa yang sudah mengusahakan ternaknya dengan menggunakan cara modern. Dengan usaha ternak yang masih bersifat tradisional ini akan berpengaruh ke jumlah populasi ternak yang relatif kecil.

Menurut Priyanto, (2016) daging sapi sebagian besar dihasilkan oleh usaha peternakan rakyat. Kebutuhan daging sapi meningkat dari tahun ke tahun, demikian pula impor terus bertambah dengan laju yang makin tinggi, baik impor daging maupun sapi bakalan. Indonesia merupakan negara net importir produk peternakan, termasuk daging sapi.

Kabupaten Timor Tengah Utara (TTU) merupakan kabupaten yang selalu mendorong masyarakat dalam pembentukan kelompok tani dan kelompok peternak. Menurut data awal yang diperoleh dari Dinas Peternakan Kabupaten TTU, kelompok tani peternak yang menerima program penyuluhan penerapan teknologi peternakan tepat guna tahun 2016 yaitu sebanyak 69 kelompok tani peternak yang tersebar di 16 kecamatan dengan jumlah anggota yang berbeda, salah satunya adalah kelompok tani Nekmese.

Kelompok Tani Nekmese adalah salah satu kelompok tani yang berada di Desa Usapinonot, Kecamatan Insana Barat. Kelompok tani ini merupakan kelompok tani tertua di Insana Barat yang dibentuk pada tahun 1998 atas inisiatif sendiri dan swadaya serta berdasarkan kesepakatan bersama. Selain berusahatani di bidang pertanian tanaman pangan dan hortikultura, kelompok tani Nekmese juga bergerak di bidang usaha pengembangbiakan dan penggemukan ternak sapi potong yang merupakan komoditi unggulan kelompok ini. Usaha penggemukan ternak sapi potong di Kelompok Tan Nekmese merupakan usaha untuk meningkatkan berat dan bobot badan ternak secara optimal dalam jangka waktu tertentu. Jenis sapi yang digemukkan di kelompok ini adalah jenis Sapi Bali.

Menurut Handayani \& Gayatri, (2005), usaha ternak sapi potong merupakan usaha yang didirikan dengan tujuan utama menghasilkan suatu produk peternakan guna memenuhi permintaan kebutuhan masyarakat akan protein hewani dan bertujuan untuk menghasilkan laba. Setiap peternak memiliki kemampuan usaha yang berbeda-beda baik dari segi kepemilikan lahan, modal, kepemilikan ternak serta sistem pengelolaan yang menyebabkan adanya perbedaan tingkat pendapatan usaha yang diterima setiap peternak Usaha ternak yang dilakukan akan lebih bermanfaat apabila tingkat pendapatan usaha yang diperoleh lebih besar daripada pengeluaran.

Menurut Falo, (2016) kegiatan usahatani ternak sapi potong meliput kegiatan pembibitan, pemeliharaan, penyediaan hijauan makanan ternak (pakan), penyediaan kandang, penyediaan air, penanganan kesehatan, produks dan produktivitas serta pemasaran. Menurut Saparinto, (2010) dalam merintis usaha termasuk usaha sapi potong, tentu harus mengetahui keunggulan produk yang akan diusahakan dan cara mendapatkan atau mengelola usahanya.

Agar usaha ternak sapi potong yang berkembang dengan baik dan memberikan manfaat bagi para anggota kelompok tani maka perlu ditentukan strategi pengembangan usaha yang tepat. Tujuan dari penelitian ini untuk mengetahui 1) gambaran kelompok tani usaha penggemukan ternak sapi potong; 2) mengetahui strategi pengembangan usaha penggemukan ternak sap potong di kelompok tani Nekmese, Desa Usapinonot, Kecamatan Insana Barat, Kabupaten TTU

\section{Metode}

Penelitian dilaksanakan di Kelompok Tani Nekmese, Desa Usapinonot, Kecamatan Insana Barat, Kabupaten TTU pada bulan November 2017 sampa April 2018. Metode yang digunakan dalam penelitian ini adalah metode surve sesuai petunjuk Singarimbun \& Soffian, (1989). Pengambilan sampel dilakukan dengan metode purposive sampling (sengaja). Sampel yang diambil dalam penelitian ini sebanyak 32 responden yang meliputi 30 responden anggota kelompok tani, satu responden dari Dinas Peternakan Kabupaten TTU dan satu orang pedagang sapi potong.

Jenis data yang digunakan adalah data primer dan data sekunder. Untuk mengetahui tujuan pertama digunakan analisis deskriptif sesuai panduan Sugiyono, (2006). Sedangkan untuk mengetahui strategi yang tepat dalam pengembangan sapi potong digunakan matriks IFAS, EFAS, dan SWOT sesuai petunjuk Rangkuti, (2002).

Analisis SWOT membandingkan faktor eksternal peluang dan ancaman dengan faktor internal kekuatan dan kelemahan. Faktor internal dimasukkan ke dalam matriks IFAS, sedangkan faktor eksternal dimasukkan ke dalam matriks EFAS dengan kriteria penilaian jumlah bobot, rating dan bobot dikalikan dengan rating kemudian ditotalkan. Setelah matriks faktor internal dan eksternal selesai disusun, hasilnya dimasukkan ke dalam matriks SWOT untuk merumuskan strategi kompetitif seperti pada Tabel 1

Tabel 1. Matriks SWOT menurut (Rangkuti, 2006)

\begin{tabular}{|c|c|c|}
\hline FAS IFAS & Kekuatan (Strength) & Kelemahan (Weakness) \\
\hline eluang (Opportunity) & $\begin{array}{c}\text { Strategi S-O } \\
\text { Ciptakan strategi yang } \\
\text { menggunakan kekuatan untuk } \\
\text { memanfaatkan peluang }\end{array}$ & $\begin{array}{c}\text { Strategi W-O } \\
\text { Ciptakan strategi yang } \\
\text { meminimalkan kelemahan untuk } \\
\text { memanfaatkan peluang }\end{array}$ \\
\hline ncaman & $\begin{array}{c}\text { Strategi S-T } \\
\text { Ciptakan strategi yang } \\
\text { menggunakan kekuatan untuk } \\
\text { mengatasi ancaman } \\
\end{array}$ & $\begin{array}{c}\text { Strategi W-T } \\
\text { Ciptakan strategi yang } \\
\text { meminimalkan kelemahan dan } \\
\text { menghindari ancaman } \\
\end{array}$ \\
\hline
\end{tabular}

\section{Hasil dan Pembahasan}

\subsection{Gambaran Umum Lokasi Penelitian}

Desa Usapinonot merupakan salah satu desa yang terletak di wilayah Kecamatan Insana Barat yang memiliki luas wilayah $13 \mathrm{~km}^{2}$ dan batas-batasnya yakni sebelah utara berbatasan dengan Desa Subun, sebelah selatan berbatasan dengan Desa Tublopo, Timur berbatasan dengan Desa Atmen dan sebelah Bara berbatasan dengan Desa Nifunenas. Keadaan topografi pada umumnya berbukit-bukit dengan ketinggian bervariasi antara 500-700 meter dpl. Keadaan pada umumnya kering dengan curah hujan yaitu musim kering mulai dari bulan April sampai bulan November dan musim hujan mulai dari bulan Desember sampai bulan Maret dengan suhu berkisar $21^{\circ} \mathrm{C}-24,5^{\circ} \mathrm{C}$. Jarak dari Desa Usapinonot ke ibukota kecamatan kurang lebih $5 \mathrm{~km}$, dan waktu tempuh 5 menit dengan menggunakan kendaraan roda dua maupun roda empat sedangkan jarak dari Desa Usapinonot ke Kota Kefamenanu kurang lebih 15 km dengan waktu tempuh 30 menit menggunakan kendaraan roda dua maupun roda empat (BPS Kab. TTU, 2017)

Jumlah penduduk Kabupaten Timor Tengah Utara tahun 2016 sebanyak 146.685 jiwa, sedangkan mata pencaharian masyarakat Kabupaten Timo Tengah Utara pada umumnya masih tergantung pada sektor pertanian. Penduduk yang bermata pencaharian sebagai petani sebanyak 60.497 jiwa dan pedagang sebanyak 6.452 jiwa. Sedangkan penduduk Kecamatan Insana Barat sesuai hasil registrasi penduduk tahun 2016 berjumlah 9.765, jiwa terdiri dari laki-laki 4.857 jiwa dan perempuan 4.908 jiwa. Jumlah KK di kecamatan 
Insana Barat sebanyak 2.553 KK dengan kepadatan penduduk $96 \mathrm{KK} / \mathrm{km}^{2}$ (BPS Kab. TTU, 2017). Sedangkan jumlah KK di Desa penelitian Usapinonot sebanyak $188 \mathrm{KK}$. Jumlah penduduk sebanyak 732 jiwa terdiri dari laki-laki 347 orang dan perempuan 385 orang.

\subsection{Gambaran Umum Kelompok Tani}

Kelompok Tani Nekmese merupakan kelompok yang terletak d Kecamatan Insana Barat Desa Usapinonot dimana kelompok ini dibentuk pada tahun 1998 atas kemauan atau inisiatif dan swadaya sendiri serta kesepakatan semua anggota kelompok tani secara bersama-sama dengan alasan pembentukan berdasarkan atas asas kekeluargaan dan untuk bekerja bersamasama menyelesaikan kegiatan kelompok maupun anggota. Anggota awal berjumlah 119 Orang dan kemudian bersepakat untuk mengurangi anggota dengan membentuk kelompok baru dan sampai saat ini kelompok tani Nekmese berjumlah 60 orang. Dalam melaksanakan kegiatan kelompok tani selalu dimusyawarahkan bersama.

Kegiatan yang dilakukan setiap anggota kelompok adalah dibidang pertanian tanaman pangan dan hortikultura, perkebunan, kehutanan dan peternakan. Di bidang peternakan usaha yang dikembangkan adalah usaha pengembangan ternak sapi (pembibitan) dan penggemukan sapi potong. Penggemukan sapi potong yang usahakan adalah sapi jantan yang berasal dari turunan induk pembibitan yang kemudian digemukkan hingga mencapai berat badan hidup berkisar 250-300 kg, kemudian dijual atau dipasarkan. Selain dari turunan ternak sapi pembibitan, ada juga ternak sapi jantan yang dibeli dari luar kelompok bahkan sampai ke luar daerah dengan standar berat awal kurang lebih $150 \mathrm{~kg}$. Cara memasarkannya yaitu dengan mendatangkan langsung pengusaha atau agen timbang ke kelompok. Cara pemasaran ini dilakukan terus menerus hingga sekarang.

Pembagian tugas dalam struktur organisasi kelompok tani Nekmese jelas dan dapat dipahami dengan baik oleh setiap anggota yaitu mengenai fungsi peran dan tupoksinya, baik dalam hal koordinasi maupun komunikasi. Sikap dan keterbukaan di antara pengurus dan anggota dapat berjalan sesuai dengan yang diharapkan. Pembagian tugas yang jelas dalam penyusunan perencanaan jenis kegiatan usahatani dilakukan dalam rapat kelompok secara terbuka dengan memberikan kesempatan kepada anggota untuk memberikan usul, saran dan memberikan masukan terhadap penyusunan rencana kegiatan kelompok. Anggota selalu aktif dan mengambil bagian dalam kegiatan untuk mencapai kesejahteraan anggota kelompok. Hubungan kerja sama dengan lembagalembaga terkait disampaikan kepada anggota melalui rapat anggota kelompok. Lembaga-lembaga terkait seperti Dinas Pertanian, Dinas Peternakan, BPTP Provinsi, Sari Tani dan lain sebagainya.

Kelompok Tani Nekmese merupakan organisasi resmi yang memiliki struktur organisasi. Struktur organisasi Kelompok Tani Nekmese terdiri dari pembimbing atau penasihat, pendamping, BPK, ketua kelompok, sekretaris, bendahara, para koordinator bidang dan anggota kelompok tani seperti pada Gambar 1.

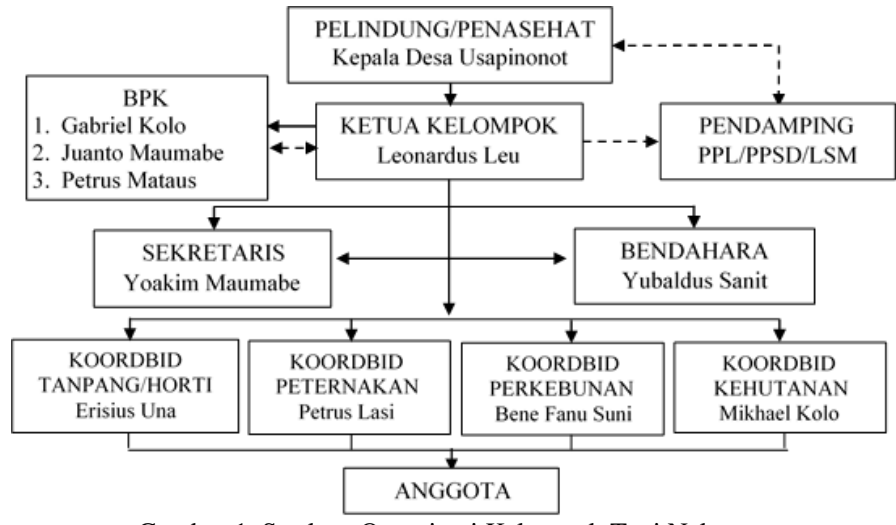

Gambar 1. Struktur Organisasi Kelompok Tani Nekmese

Berdasarkan struktur organisasi maka tugas dan peran masing-masing pengurus adalah sebagai berikut:

a. Pelindung atau penasihat, yang menjadi tugas seorang pelindung atau penasihat yaitu memberikan masukan dan arahan-arahan serta hal teknis lainnya.

b. BPK (Badan Pemeriksa Keuangan), yang menjadi tugas BPK yaitu mengawasi administrasi keuangan kelompok.

c. Pendamping, pendamping bertugas mendampingi program-program dan kegiatan kelompok yang dijalankan mulai dari pendataan sampai dengan laporan.

d. Ketua Kelompok, mengkoordinasikan, mengorganisasikan dan bertanggungjawab terhadap seluruh kegiatan kelompok. Tugas ketua kelompok dapat dirincikan yakni memimpin rapat pengurus, memimpin rapat anggota, menandatangani surat-menyurat dan mewakili kelompok dalam pertemuan dengan pihak lainnya serta melaporkan hasil kegiatan atau bertanggungjawab ke dinas terkait.

e. Sekretaris, yang menjadi tugas sekretaris kelompok dirincikan yakni mencatat keputusan-keputusan dalam rapat, menindaklanjuti hasil-hasil rapat dengan membuat notulen, menata administrasi non keuangan dan menyiapkan surat-menyurat dan pengarsipan serta laporan-laporan baik bulanan maupun tahunan.

f. Bendahara, tugas dari seorang bendahara kelompok yaitu menangani dan mengelola kegiatan administrasi keuangan dapat dirincikan yakni menerima dan melakukan pembayaran atas nama kelompok atas persetujuan ketua dan anggota kelompok, menyusun laporan keuangan kelompok dan menyimpan arsip transaksi keuangan.

g. Koordinator Bidang (Tanaman Pangan dan Hortikultura, Peternakan, Perkebunan dan Kehutanan), tugas dari seorang koordinator bidang dapat dirincikan yakni merancang kegiatan kelompok dibidang masing-masing, melaksanakan dan menggerakkan semua anggota kelompok, mengkoordinir kegiatan terkait dan bertanggungjawab kepada ketua kelompok

\subsection{Faktor Internal dan Eksternal}

a. Kekuatan

Kekuatan yang dimiliki oleh usaha penggemukan sapi di kelompok tani Nekmese adalah i) peternak yang berpengalaman dalam berusaha ternak penggemukan sapi potong; ii) anggota kelompok mengikuti pelatihan atau Diklat usaha ternak sapi potong; iii) pakan hijauan di alam (dibudidaya atau alam bebas), air minum ternak maupun vaksinasi dan pengobatan tersedia; iv) makanan tambahan seperti pengolahan pakan konsentrat berupa hay dan silase dikondisikan; v) kegiatan usaha penggemukan ternak yang berada di dalam satu lokasi yang terpusat; vi) petugas teknis peternakan selalu ada di desa; vii) adanya koperasi kelompok tani; dan ix) daging sapi hasil penggemukan berkualitas tinggi.

b. Kelemahan

Kelemahan yang dimiliki oleh usaha penggemukan sapi di kelompok tani Nekmese adalah i) sebagian besar anggota kelompok tani berpendidikan rendah (SD); ii) kurang memahami pemilihan bibit sapi yang tepat; iii) usaha penggemukan yang tidak efisien atau melebihi target waktu yang sesuai standar penggemukan yakni 6 bulan; dan iv) pemilihan bobot atau berat awal dalam usaha penggemukan ternak sapi potong yang tidak tepat.

c. Peluang

Peluang yang dimiliki oleh usaha penggemukan sapi di kelompok tani Nekmese adalah i) harga daging sapi yang terus meningkat; ii) penjualan ternak dengan cara langsung mendatangkan pedagang atau pengusaha timbang ke lokasi usaha kelompok; iii) adanya program pemerintah yang mendukung kelompok tani; iv) adanya penyuluh peternakan yang siap mendampingi; dan v) adanya bantuan obat-obatan dari Dinas Peternakan.

d. Ancaman

Ancaman terhadap usaha penggemukan sapi di kelompok tani Nekmese adalah i) pakan yang diambil dari alam masih dihinggapi ulat beracun; ii) penyakit antraks yang mampu mematikan; iii) pembersihan dan pembuangan limbah ternak yang tidak jauh dari kandang ternak; dan iv) pertumbuhan fisik dan pertambahan bobot ternak sapi potong yang lambat.

\subsection{Alternatif Strategi Pengembangan Usaha}

a. Strategi S-O (Strength-Opportunity)

Merupakan strategi yang menggunakan kekuatan internal untuk dapat memanfaatkan peluang eksternal. Alternatif strategi S-O yang dirumuskan yaitu i) meningkatkan jumlah ternak sapi potong untuk memenuhi kebutuhan pasar; ii) mengoptimalkan kemampuan peternak dalam mengembangkan usaha penggemukan ternak sapi potong; dan iii) ciptakan suatu wadah yang dapat menampung dan mengelola sendiri modal usaha kelompok.

b. Strategi W-O (Weakness-Opportunity)

Merupakan strategi yang dapat meminimalkan kelemahan internal untuk dapat memanfaatkan peluang eksternal. Alternatif strategi W-O yang dirumuskan yaitu i) mengembangkan dan meningkatkan kemampuan SDM peternak dalam berusaha ternak sapi potong; dan ii) membuka peluang jaringan kerjasama dengan berbagai pihak baik dalam hal pengembangan usaha maupun pemasaran ternak.

c. Strategi S-T (Strength-Threat)

Merupakan strategi yang dapat mengoptimalkan kekuatan internal yang ada dalam menghindari ancaman dari luar. Alternatif strategi S-T yang dirumuskan yaitu i) mengadakan pelatihan pengenalan pakan dan waktu pengambilan pakan serta pemberian pakan; dan ii) pengadaan pelatihan mengenai penggunaan obat-obatan dan pemberian kekebalan tubuh serta sanitasi yang aman bagi ternak sapi potong.

d. Strategi W-T (Weakness-Threat)

Merupakan strategi defensif untuk meminimalkan kelemahan internal dan menghindari ancaman eksternal. Alternatif strategi W-T yang dirumuskan yaitu i) mengadakan pelatihan dan pemberdayaan kepada peternak dan SDM petugas teknis peternakan di desa; dan ii) melakukan pembinaan atau pelatihanpelatihan kepada peternak untuk meningkatkan dan mempertahankan bobot badan maupun kualitas ternak sapi potong.

\section{Simpulan}

Kekuatan yang dimiliki oleh usaha penggemukan sapi di kelompok tani Nekmese adalah i) peternak yang berpengalaman dalam berusaha ternak penggemukan sapi potong; ii) anggota kelompok mengikuti pelatihan atau Diklat usaha ternak sapi potong; iii) pakan hijauan di alam (dibudidaya atau alam bebas), air minum ternak maupun vaksinasi dan pengobatan tersedia; iv) 
makanan tambahan seperti pengolahan pakan konsentrat berupa hay dan silase dikondisikan; v) kegiatan usaha penggemukan ternak yang berada di dalam satu lokasi yang terpusat; vi) petugas teknis peternakan selalu ada di desa; vii) adanya koperasi kelompok tani; dan ix) daging sapi hasil penggemukan berkualitas tinggi. Kelemahan yang dimiliki oleh usaha penggemukan sapi di kelompok tani Nekmese adalah i) sebagian besar anggota kelompok tani berpendidikan rendah (SD); ii) kurang memahami pemilihan bibit sapi yang tepat; iii) usaha penggemukan yang tidak efisien atau melebihi target waktu yang sesuai standar penggemukan yakni 6 bulan; dan iv) pemilihan bobot atau berat awal dalam usaha penggemukan ternak sapi potong yang tidak tepat.

Peluang yang dimiliki oleh usaha penggemukan sapi di kelompok tani Nekmese adalah i) harga daging sapi yang terus meningkat; ii) penjualan ternak dengan cara langsung mendatangkan pedagang atau pengusaha timbang ke lokasi usaha kelompok; iii) adanya program pemerintah yang mendukung kelompok tani; iv) adanya penyuluh peternakan yang siap mendampingi; dan v) adanya bantuan obat-obatan dari Dinas Peternakan. Ancaman terhadap usaha penggemukan sapi di kelompok tani Nekmese adalah i) pakan yang diambil dari alam masih dihinggapi ulat beracun; ii) penyakit antraks yang mampu mematikan; iii) pembersihan dan pembuangan limbah ternak yang tidak jauh dari kandang ternak; dan iv) pertumbuhan fisik dan pertambahan bobot ternak sapi potong yang lambat.

Alternatif strategi S-O yang dirumuskan yaitu i) meningkatkan jumlah ternak sapi potong untuk memenuhi kebutuhan pasar; ii) mengoptimalkan kemampuan peternak dalam mengembangkan usaha penggemukan ternak sapi potong; dan iii) ciptakan suatu wadah yang dapat menampung dan mengelola sendiri modal usaha kelompok. Alternatif strategi W-O yang dirumuskan yaitu i) mengembangkan dan meningkatkan kemampuan SDM peternak dalam berusaha ternak sapi potong; dan ii) membuka peluang jaringan kerjasama dengan berbagai pihak baik dalam hal pengembangan usaha maupun pemasaran ternak. Alternatif strategi S-T yang dirumuskan yaitu i) mengadakan pelatihan pengenalan pakan dan waktu pengambilan pakan serta pemberian pakan; dan ii) pengadaan pelatihan mengenai penggunaan obat-obatan dan pemberian kekebalan tubuh serta sanitasi yang aman bagi ternak sapi potong. Alternatif strategi W-T yang dirumuskan yaitu i) mengadakan pelatihan dan pemberdayaan kepada peternak dan SDM petugas teknis peternakan di desa; dan ii) melakukan pembinaan atau pelatihan-pelatihan kepada peternak untuk meningkatkan dan mempertahankan bobot badan maupun kualitas ternak sapi potong.

\section{Pustaka}

BPS Kab. TTU 2017. Kabupaten Timor Tengah Utara dalam Angka 2017. Kefamenanu: Badan Pusat Statistik Kabupaten TTU.

Falo, M. 2016. Kajian Dinamika Kelompok Tani Usaha Ternak Sapi Potong di Kelompok Tani Nekmese Desa Manusasi Kecamatan Miomaffo Barat. AGRIMOR, 1(01): 15-18.

Handayani, M. \& Gayatri, S. 2005. Pendapatan Tenaga Kerja Keluarga pada Usaha Ternak Sapi Potong di Kecamatan Toroh Kabupaten Grobogan. Mediagro, 1(2): 38-44.

Kurniawan, E. 2012. Analisis Potensi Pengembangan Peternakan Sapi Potong di Kecamatan Bungkal Kabupaten Ponorogo. Skripsi. Surakarta: Universitas Sebelas Maret.

Priyanto, D. 2016. Strategi Pengembangan Usaha Ternak Sapi Potong dalam Mendukung Program Swasembada Daging Sapi dan Kerbau Tahun 2014. Jurnal Penelitian dan Pengembangan Pertanian, 30(3): 108-116.

Rangkuti, F. 2002. Analisis SWOT Teknik Membedah Kasus Bisnis: Reorientasi Konsep Perencanaan Strategi untuk Menghadapi Abad 21. Jakarta: Gramedia Pustaka Utama.

Rangkuti, F. 2006. Analisis Swot Teknik Membedah Kasus Bisnis. Jakarta: Gramedia Pustaka Utama.

Saparinto, P.Y., Cahyo 2010. Pembesaran Sapi Potong Secara Intensif. Jakarta: PT Niaga Swadaya.

Singarimbun, M. \& Soffian, E. 1989. Metode Penelitian Survei. Jakarta: LP3ES.

Sugiyono, 2006. Metode Penelitian Kuantitatif, Kualitatif dan $R \& D$. Bandung: Alfabeta. 